\title{
THE CONTENT OF TOPSOIL NUTRIENTS, pH AND ORGANIC CARBON AS AFFECTED BY LONG-TERM APPLICATION OF MINERAL AND ORGANIC FERTILISERS
}

\author{
LUKÁŠ HLISNIKOVSKÝ, EVA KUNZOVÁ*
}

Crop Research Institute, Prague

\begin{abstract}
HLISNIKOVSKÝ, L. - KUNZOVÁ, E.: The content of topsoil nutrients, pH and organic carbon as affected by long-term application of mineral and organic fertilisers. Agriculture (Pol'nohospodárstvo), vol. 60, 2014, no. 4, pp. 142-148.
\end{abstract}

Soil is the fundamental element in agriculture and is affected in a variety of ways. Besides other things, the long-term application of mineral and organic fertilisers can significantly influence the topsoil pool of nutrients, organic carbon content and $\mathrm{pH}$. Within the scope of longterm field experiments in Praha-Ruzyně, we evaluated the effect of six fertiliser treatments - unfertilised Control, farmyard manure (FYM), cattle slurry (CAT), cattle slurry amended with straw from previous cereals (CAT+STR), mineral fertiliser (NPK) and NPK amended with FYM (NPK+FYM) on a topsoil pool of nutrient content, organic carbon content (Cox) and $\mathrm{pH}$ between the years 2001 and 2012. In the selected period, the fertiliser treatment did not influence the $\mathrm{N}$ and Cox content (ranging from $0.126 \%$ to $0.143 \%$ ). Phosphorus and potassium were sig- nificantly higher in the NPK+FYM treatment (109.82 and $279.27 \mathrm{mg} / \mathrm{kg}$, respectively), while calcium and magnesium were significantly lower in the NPK treatment (2,973 and $134.95 \mathrm{mg} / \mathrm{kg}$, respectively). Application of mineral fertilisers significantly decreased the value of $\mathrm{pH}$, influencing the $\mathrm{Ca}$ and $\mathrm{Mg}$ topsoil concentrations. Organic fertilisers cannot provide a sustainable amount of nutrients to generate high yields in a short time, but release their nutrients slowly and the range of nutrients is wider. Mineral fertilisers, if not amended with organic fertilisers, can provide huge doses of nutrients, which can be quickly reused for high yields, but negatively influence the $\mathrm{pH}$ value, resulting in a decrease in the pool of $\mathrm{Ca}$ and $\mathrm{Mg}$.

Key words: soil, nutrient pool, cattle slurry, farmyard manure, NPK

Application of mineral and organic fertilisers on arable soil is accompanied by many pros and cons. Due to fertilisers, farmers can increase the potential yields and quality of arable crops and provide sustainable production of raw materials to fulfil the increasing demands from the food-processing industry. Furthermore, organic and mineral fertilisers can have a beneficial effect on soil characteristics and fertility by increasing soil organic carbon in topsoils (Hati et al. 2006; Sradnick et al. 2014), water holding capacity, saturated hydraulic conductivity (Zhang et al. 2014), microbial biomass (Geisseler \& Scow 2014) and decreasing bulk density (Bandyopadhyay et al. 2010; Zhang et al. 2014). Application of cattle manure can increase the total $\mathrm{N}$ concentration in the upper soil layers (Zhengchao et al. 2013). Application of $\mathrm{N}$ can significantly increase the content of Fe and Mn, and application of FYM can significantly increase $\mathrm{Cu}$ and $\mathrm{Zn}$ in topsoils (Zhang et al. 2014).

On the other hand, over-fertilisation of arable soils (especially the use of nitrogen) can cause serious harm to the environment via ground and surface water pollution and also significant financial losses (Raun \& Johnson 1999). The combination of mineral and organic fertilisers can cause environmental damages as many farmers do not consider organic fertilisers, pig slurry specifically, as fertiliser, but as

Ing. Hlisnikovský Lukáš, Ing. Kunzová Eva, CSc. (*Corresponding author), Department of Nutrition Management, Crop Research Institute, Drnovská 507, CZ-16101 Prague 6, Ruzyně, Czech Republic. E-mail: kunzova@vurv.cz 
a waste product. As a consequence, farmers do not reduce the total amount of mineral nutrients, harming the environment (Berenguer et al. 2008).

Within the framework of a long-term crop rotation experiment in Prague-Ruzyně, established in 1954, we evaluated the effect of six fertiliser treatments on the topsoil $(0-20 \mathrm{~cm})$ content of nutrients (N, $\mathrm{P}, \mathrm{K}, \mathrm{Ca}, \mathrm{Mg}$ ), organic carbon content (Cox) and pH between the years 2001 and 2012 .

\section{MATERIAL AND METHODS}

\section{Site description}

The Ruzyně Fertiliser Experiment (RFE) was established on a permanent arable field in 1954, on the western edge of Prague. At the study site, the longtime mean annual temperature is $8.8 \pm 7.5^{\circ} \mathrm{C}$ and the mean annual precipitation is $519.7 \pm 23 \mathrm{~mm}$ (PragueRuzyně Meteorological Station 1953-2013). During the time of our experiment (2001-2012), the mean annual temperature and precipitation were higher, as the temperature increased to $9.5 \pm 7.5^{\circ} \mathrm{C}$ and precip- itation to $552.4 \pm 26.5 \mathrm{~mm}$ (Figure 1). According to World Reference Base for Soil Resources (2nd ed., revised, 2007), the soil type was classified as Luvisol (LV). The parent material is loess mixed with highly weathered chalk. The ground water level is $20 \mathrm{~m}$ below the field surface. The upper $30 \mathrm{~cm}$ (arable layer) contains $27 \%$ clay, increasing to $40 \%$ in the subsoil (soil layer $30-40 \mathrm{~cm}$ ) and $49 \%$ at $40-50$ cm depth.

\section{Experimental design}

The RFE consists of four strips (I, II, III and IV). Each strip is divided into 96 experimental plots, where a total of 24 variants of fertiliser treatments in four replications are running $(24 \times 4=96)$. The size of the individual plot is $12 \times 12 \mathrm{~m}$. To eliminate the edge effect, only the central $5 \times 5 \mathrm{~m}$ area is used for sample collection. A more detailed description of RFE is available in Hejcman et al. (2012). Data, evaluated in this paper are from the strip IV. Out of 24 fertiliser treatments, only 6 variants were evaluated in this paper. These are: Control (non-fertilised from 1954), FYM, CAT, CAT+STR, mineral fer-

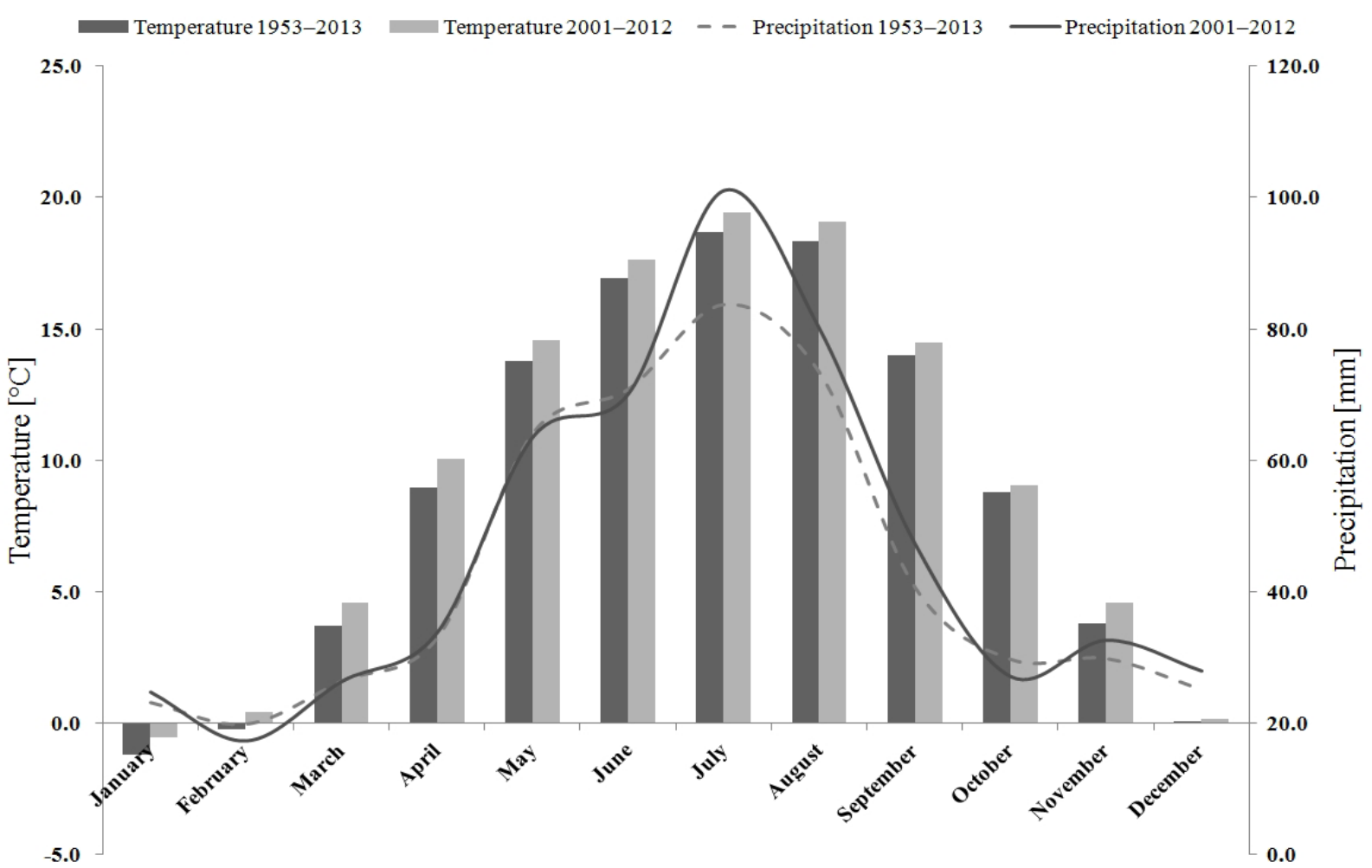

Figure 1. Comparison of the mean monthly temperature $\left[{ }^{\circ} \mathrm{C}\right]$ and precipitation $[\mathrm{mm}]$ between 1953 and 2013 (longtime means) and 2001 and 2012 (means during the experiment) 
tilisers (NPK) and NPK+FYM. The FYM and CAT were applied in the autumn and only to root crops in the crop rotation. STR was ploughed back into the land only after cereals. Nitrogen, phosphorus and potassium were applied as ammonium nitrate with lime, $27 \% \mathrm{~N}$, triple superphosphate, $19.4 \% \mathrm{P}$ and potassium chloride, $49.8 \% \mathrm{~K}$. Nitrogen was applied in the spring, and phosphorus and potassium were applied in the autumn before sowing. The crop rotation is composed of $45 \%$ of cereals, $33 \%$ of roots and $22 \%$ of fodder. The specific crop rotation with exact rates of applied organic and mineral fertilisers is shown in Table 1. Photography of the experimental site is shown in Figure 2.

\section{Soil analysis}

Soil samples [depth of $0-0.2 \mathrm{~m}$ ] were recovered every autumn before fertilisers were applied. To analyse the content of nitrogen [\%], soil samples were decomposed with concentrated sulphuric acid in a heating block (Tecator, Sweden), followed by the Kjeldahl method analysis. Phosphorus, potassium, calcium and magnesium $[\mathrm{mg} / \mathrm{kg}]$ were analysed through Mehlich 3 (Mehlich 1984) and then by ICP OES (Integra XL, GBC Scientific Equipment, Aus- tralia). The $\mathrm{pH}$ value was analysed through ionometric measurement in $\mathrm{KCl}$. Cox [\%] was analysed by oxidation in a dichromate digestion solution (Zbíral et al. 1997).

\section{Statistical analysis}

All statistical analyses were performed using STATISTICA 12.0 software (www.StatSoft.com). The effect of the treatment was analysed by oneway analysis of variance (ANOVA). After obtaining significant ANOVA results, a Tukey HSD post hoc

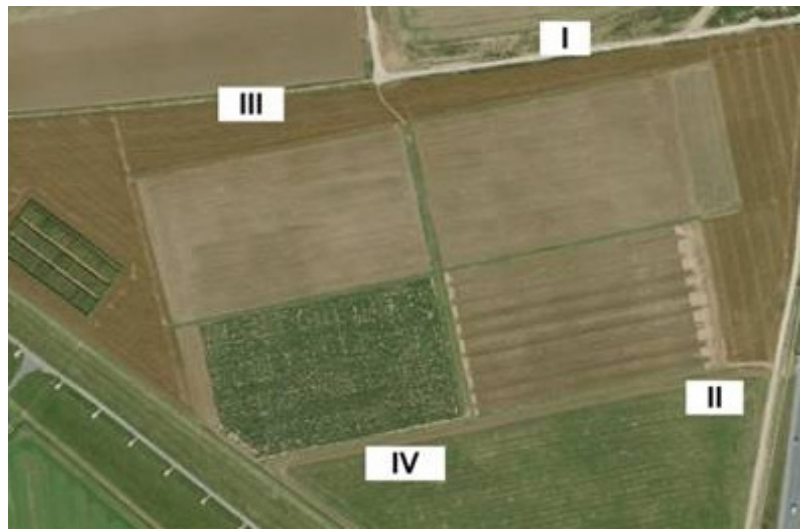

Figure 2. Aerial photograph of Ruzyně Fertiliser Experiment (RFE) strips I-IV

$\mathrm{T}$ a b 1 e 1

The crop rotation and doses of organic $[\mathrm{Mg} / \mathrm{ha}]$ and mineral $[\mathrm{kg} / \mathrm{ha}]$ fertilisers on strip IV between 2000 and 2012

\begin{tabular}{|l|c|c|c|c|c|c|}
\hline Year & Crop rotation & $\begin{array}{c}\mathrm{FYM} \\
{[\mathrm{Mg} / \mathrm{ha}]}\end{array}$ & $\begin{array}{c}\mathrm{CAT} \\
{[\mathrm{Mg} / \mathrm{ha}]}\end{array}$ & $\begin{array}{c}\text { CAT+STR } \\
{[\mathrm{Mg} / \mathrm{ha}]}\end{array}$ & $\begin{array}{c}\mathrm{N}, \mathrm{P}, \mathrm{K} \\
{[\mathrm{kg} / \mathrm{ha}]}\end{array}$ & $\begin{array}{c}\mathrm{NPK}+\mathrm{FYM} \\
{[\mathrm{kg} / \mathrm{ha} ; \mathrm{Mg} / \mathrm{ha}]}\end{array}$ \\
\hline 2000 & Solanum tuberosum L. & 15 & 32 & 32 & $110,70,224$ & $110,70,224+15$ \\
2001 & Triticum aestivum L. & - & - & - & $95,60,120$ & $95,60,120$ \\
2002 & Beta vulgaris L. & 21 & 45 & 45 & $200,80,200$ & $200,80,200+21$ \\
2003 & Hordeum vulgare L. & - & - & - & $70,60,100$ & $70,60,100$ \\
2004 & Medicago sativa L. & - & - & - & $0,70,220$ & $0,70,220$ \\
2005 & Medicago sativa L. & - & - & - & $0,100,300$ & $0,100,300$ \\
2006 & Triticum aestivum L. & - & - & - & $75,60,120$ & $75,60,120$ \\
2007 & Beta vulgaris L. & 21 & 45 & 45 & $200,80,200$ & $200,80,200+21$ \\
2008 & Hordeum vulgare L. & & & & $70,60,100$ & $70,60,100$ \\
2009 & Solanum tuberosum L. & 15 & 32 & 32 & $110,70,224$ & $110,70,224+15$ \\
2010 & Triticum aestivum L. & - & - & - & $95,60,120$ & $95,60,120$ \\
2011 & Beta vulgaris $\mathrm{L}$. & 21 & 45 & 45 & $200,80,200$ & $200,80,200+21$ \\
2012 & Hordeum vulgare L. & - & - & - & $70,60,100$ & $70,60,100$ \\
\hline
\end{tabular}


test was applied to determine significant differences among individual treatments.

\section{RESULTS AND DISCUSSION}

Application of mineral and organic fertilisers did not significantly influence the total soil $\mathrm{N}$ content between the years 2001 and 2012 (d.f. $=5, \mathrm{~F}=0.354$, $p=0.878)$. The highest $\mathrm{N}$ content in topsoil was recorded in the NPK+FYM treatment $(0.143 \%)$, while the lowest was in the Control treatment $(0.126 \%)$ (Figure 3a). No statistical differences between Control (without any fertiliser inputs from 1954) and NPK +FYM treatments can be probably explained by several factors. The first factor is a strict compliance with crop rotation, which includes $22 \%$ of legumes. Legumes can be a sustainable source of nitrogen in agricultural systems (Peoples et al. 1995). According to Yang et al. (2010), the adjusted average $\mathrm{N}_{2}$ fixation rate of alfalfa is $218 \mathrm{~kg} \mathrm{~N} / \mathrm{ha}$, ranging from 141 to $300 \mathrm{~kg} \mathrm{~N} / \mathrm{ha}$. The second factor is the loss of nitrogen to the atmosphere and due to drainage. Jenkinson (1991) concluded that approximately $30 \%$ of the total nitrogen entering the plant/ soil system of the Broadbalk Wheat Experiment at Rothamsted each year is lost. The leached $\mathrm{N}$ comes from mineralisation of soil organic matter and not unused fertiliser residues. With a higher content of soil organic matter, the loss increases and the differences between treatments are not retained. Finally, nitrogen is the most limiting element for yields. The $\mathrm{NPK}+\mathrm{FYM}$ is the treatment providing one of the highest yields in the RFE (Hlisnikovský \& Kunzová 2014), which is associated with a high $\mathrm{N}$ demand and its use.

T a

The evaluation of $\mathrm{P}, \mathrm{K}$ and $\mathrm{Mg}$ soil content $[\mathrm{mg} / \mathrm{kg}$ ] (Mehlich 3) according to Budňáková et al. (2004)

\begin{tabular}{|l|c|c|c|}
\hline Element/Range & $\mathrm{P}$ & $\mathrm{K}$ & $\mathrm{Mg}$ \\
\hline Low & $<50$ & $<105$ & $<105$ \\
Suitable & $51-80$ & $106-170$ & $106-160$ \\
Good & $81-115$ & $171-310$ & $161-265$ \\
High & $116-185$ & $311-420$ & $266-330$ \\
Very high & $>185$ & $>420$ & $>330$ \\
\hline
\end{tabular}

Phosphorus and potassium soil content exhibited a reciprocal relation. Both elements were significantly influenced by fertiliser treatment (P: d.f. $=5$, $\mathrm{F}=52.52, p=0.01 ; \mathrm{K}:$ d.f. $=5, \mathrm{~F}=26.18, p=0.001)$, both elements have had the highest concentrations in NPK+FYM treatment (109.82 and $279.27 \mathrm{mg} / \mathrm{kg}$ respectively) and the lowest in the Control treatment ( 25.00 and $139.45 \mathrm{mg} / \mathrm{kg}$ respectively; see Figure $3 b, 3 c)$. According to Budnáková et al. (2004), the concentration of $\mathrm{P}$ in the NPK+FYM treatment is classified as 'good', while in the NPK treatment, it is just 'suitable' and 'low' in all other treatments (Table 2). It means that application of organic fertilisers, without mineral fertiliser amendment, cannot provide a sufficient amount of nutrients to create high yields and increase the soil nutrient pool for the next arable crops.

Calcium and magnesium content also showed a similar pattern. The contents of both elements were significantly influenced by fertiliser treatment (Ca: d.f. $=5, \mathrm{~F}=16.64, p=0.001 ; \mathrm{Mg}$ : d.f. $=5$, $\mathrm{F}=14.59, p=0.001)$. The highest concentrations of $\mathrm{Ca}(3,680 \mathrm{mg} / \mathrm{kg})$ and $\mathrm{Mg}(196.45 \mathrm{mg} / \mathrm{kg})$ were recorded in the CAT + STR treatment in both cases, with the lowest $(2,973 \mathrm{mg} / \mathrm{kg}$ and $134.95 \mathrm{mg} / \mathrm{kg}$, respectively) in the NPK treatment (Figure 3d, 3e). The higher concentrations of $\mathrm{Ca}$ and $\mathrm{Mg}$ in organic treatments can be explained by two factors. First, organic fertilisers contain a big scale of nutrients in smaller rates. Thus, they provide a regular supply of not only $\mathrm{N}, \mathrm{P}$ and $\mathrm{K}$, but also $\mathrm{Ca}, \mathrm{Mg}$ and others. Second, concentrations of $\mathrm{Ca}$ and $\mathrm{Mg}$ were strongly associated with the $\mathrm{pH}$ value. The highest mean $\mathrm{pH}$ value was recorded in the CAT treatment (6.61), while the lowest was in the NPK treatment (5.66; see Figure $3 \mathrm{~g}$ ). The correlation relationship was strongly positive between $\mathrm{Ca}$ and $\mathrm{pH}(r=0.9)$ and medium positive between $\mathrm{Mg}$ and $\mathrm{pH}(r=0.55)$. Application of mineral fertilisers significantly decreased the $\mathrm{pH}$ value in our experiment and strongly influenced the $\mathrm{Ca}$ and $\mathrm{Mg}$ topsoil content. This is in agreement with Barak et al. (1997), who also recorded a negative change in $\mathrm{pH}, \mathrm{Ca}$ and $\mathrm{Mg}$ concentrations accompanied by increasing $\mathrm{N}$ rates, or with Wang et al. (2003). Amendment of FYM to NPK can particularly smooth down the negative effect of NPK as the $\mathrm{pH}$ and concentrations of $\mathrm{Ca}$ and $\mathrm{Mg}$ were slightly higher, when compared to NPK. 


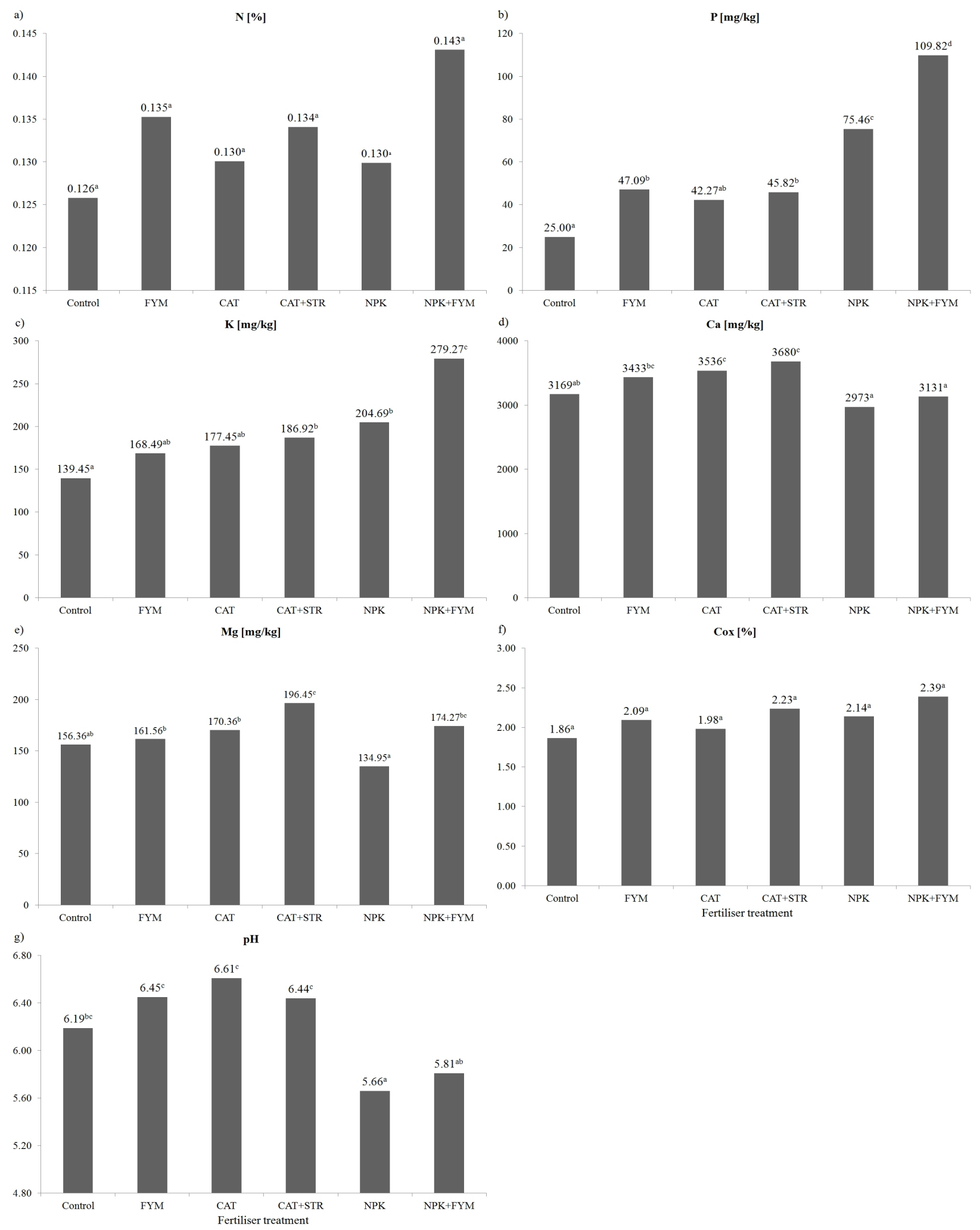

Figure 3. The concentration of a) nitrogen [\%], b) phosphorus [mg/kg], c) potassium $[\mathrm{mg} / \mathrm{kg}]$, d) calcium [mg/kg], e) magnesium $[\mathrm{mg} / \mathrm{kg}]$, f) organic carbon [\%] and $\mathrm{g}$ ) $\mathrm{pH}$ as affected by fertiliser treatment (Control, FYM, CAT, CAT+STR, NPK, NPK+FYM) between 2001 and 2012. Different letters indicate significant differences $(p<0.05)$ between treatments. 
No significant differences between fertiliser treatments were observed in the case of Cox (d.f. $=5$, $\mathrm{F}=0.384, p=0.858)$. The highest Cox was recorded in the NPK+FYM treatment $(2.39 \%)$ and the lowest in the Control treatment (1.86\%) (Figure 3f). This is contrary to the results of Zhengchao et al. (2013), who recorded a significant increase in soil organic carbon concentration between different mineral fertilisation treatments in the 26-year experiment. There are a few ways in which fertilisers enrich the soil $\mathrm{N}$ and Cox content. First, organic fertilisers provide a medium amount of carbon and other nutrients. However, those nutrients are slowly degraded and it takes time to integrate them back to the soil-plant system. According to Pratt et al. (1973), $35 \%$ of the total $\mathrm{N}$ in manure was available to crops during the first year and only $10 \%$ and $5 \%$ in the second and the third year after application. According to Klausner et al. (1994), only $9 \%$ of the total N applied by manure was released in the second year and $3 \%$ in the third year after manure application. On the other hand, mineral fertilisers provide a huge amount of nutrients, which can be relatively quickly absorbed by plants, leading to the development of a rich root system and thus higher yields (Hejcman et al. 2012) under good weather conditions. The ratio of fertiliser mineralisation decreases during dry seasons and increases during wet seasons, when the soil moisture is near the field capacity (Cassman \& Munns 1980). Under unsuitable weather conditions, even high doses of mineral fertilisers cannot provide sufficient yields (Hlisnikovský et al. 2014). If the aboveground parts of the arable crops are not returned back to the soil by ploughing or tillage, as in our case (except for the CAT+STR treatment), the biggest source of Cox and $\mathrm{N}$ remains in decaying roots. Those factors can explain the differences between the Cox topsoil content of specific fertiliser treatments.

\section{CONCLUSION}

Between 2001 and 2012, application of organic and mineral fertilisers did not significantly influence the $\mathrm{N}$ and Cox topsoil content. The $\mathrm{N}$ content increased in the order: Control $<$ CAT, NPK $<$ CAT+STR $<$ FYM $<$ NPK +FYM; Cox showed a sim- ilar pattern. As the aboveground parts of the plants are not returned back to the soil in our experiment (except in one treatment), the higher $\mathrm{N}$ and Cox contents in well-fertilised treatments are caused due to a richer root system, the only source of organic material. Phosphorus and potassium concentrations did not differ significantly between organic treatments; the content was equal, but was significantly higher in NPK and NPK+FYM treatments. Calcium and magnesium concentrations behaved oppositely. While regular application of high doses of mineral nutrients can provide high yields and leave a relatively good pool of nutrients in the soil, organic fertilisers release more nutrients $(\mathrm{N}, \mathrm{P}, \mathrm{K}, \mathrm{Ca}, \mathrm{Mg}$ and others) in smaller doses and in a longer period. If the application of mineral fertilisers is not amended with regular application of $\mathrm{Ca}$, the soil pool of those nutrients can decrease significantly and negatively influence the $\mathrm{pH}$ value. Thus, the combined application of mineral NPK and FYM provides a wide range of nutrients, which are released in both, short and long periods, and reduce the negative effect of NPK on topsoil $\mathrm{pH}$.

Acknowledgements. The writing of the paper was supported by the Ministry of Agriculture of the Czech Republic, Projects No. MZE RO0414 and QJ 1210211.

\section{REFERENCES}

BANDYOPADHYAY, K.K. - MISRA, A.K. - GHOSH, P.K. - HATI, K.M. 2010. Effect of integrated use of manure and chemical fertilizers on soil physical properties and productivity of soybean. In Soil and Tillage Research, vol. 110, pp. 115-125. DOI:10.1016/j. still.2010.07.007

BARAK, P. - JOBE, B.O. - KRUEGER, A.R. - PETERSON, L.A. - LAIRD, D.A. 1997. Effects of long-term soil acidification due to nitrogen fertilizer inputs in Wisconsin. In Plant and Soil, vol. 197, pp. 61-69.

BERENGUER, P. - SANTIVERI, F. - BOIXADERA, J. LLOVERAS, J. 2008. Fertilisation of irrigated maize with pig slurry combined with mineral nitrogen. In European Journal of Agronomy, vol. 28, pp. 635-645. DOI:10.1016/j.eja.2008.01.010.

BUDŇÁKOVÁ, M. - ČERMÁK, P. - HAUERLAND, M. - KLÍR, J. 2004. Zákon o hnojivech a navazující vyhlášky [Fertilisers Act and related edicts]. ÚZPI : Prague.

CASSMAN, K.G. - MUNNS, D.N. 1980. Nitrogen mineralization as affected by soil moisture, temperature, 
and depth. In Soil Science Society of America Journal, vol. 44, no. 6 pp. 1233-1237. DOI:10.2136/SSS AJ1980.03615995004400060020X.

GEISSELER, D. - SCOW, K.M. 2014. Long-term effects of mineral fertilizers on soil microorganism A review. In Soil Biology \& Biochemistry, vol. 75, pp. 54-63. DOI:10.1016/j.soilbio.2014.03.023.

HATI, K.M. - MANDAL, K.G. - MISRA, A.K. - GHOSH, P.K. - BANDYOPADHYAY, K.K. 2006. Effect of inorganic fertilizer and farmyard manure on soil physical properties, root distribution, and water-use efficiency of soybean in Vertisols of central India. In Bioresource Technology, vol. 97, pp. 2182-2188. DOI: 10.1016/j.biortech.2005.09.033.

HEJCMAN, M. - KUNZOVÁ, E. - ŠREK, P. 2012. Sustainability of winter wheat production over 50 years of crop rotation and $\mathrm{N}, \mathrm{P}$ and $\mathrm{K}$ fertilizer application on illimerized luvisol in the Czech Republic. In Field Crop Research, vol. 139, pp. 30-38. DOI:10.1016/j. fcr.2012.10.005.

HLISNIKOVSKÝ, L. - KUNZOVÁ, E. 2014. Effect of mineral and organic fertilizers on yield and technological parameters of winter wheat (Triticum aestivum L.) on illimerized Luvisol. In Polish Journal of Agronomy, vol. 17, pp. 18-24.

HLISNIKOVSKÝ, L. - KUNZOVÁ, E. - HEJCMAN, M. - DVOŘÁČEK, V. 2014. Effect of fertilizer application, soil type, and year on yield and technological parameters of winter wheat (Triticum aestivum) in the Czech Republic. In Archives of Agronomy and Soil Science, vol. 61, pp. 33-53. DOI: 10.1080/03650340.2014.921808.

JENKINSON, D.S. 1991. The Rothamsted long-term experiments: Are they still of use? In Agronomy Journal, vol. 83, pp. 2-10. DOI:10.2134/agronj1991.00021962008300010008x.

KLAUSNER, S.D. - KANNEGANTI, V.R. - BOULDIN, D.R. 1994. An approach for estimating a decay series for organic nitrogen in animal manures. In Agronomy Journal, vol. 86, pp. 897-903. DOI:10.2134/agronj1994.00021962008600050026x.

MEHLICH, A. 1984. Mehlich 3 soil test extractant: A modification of Mehlich 2 extractant. In Communications in Soil Science and Plant Analysis, vol. 15, pp. 1409-1416.

PEOPLES, M.B. - HERRIDGE, D.F. - LADHA, J.K. 1995. Biological nitrogen fixation - an efficient source of nitrogen for sustainable agricultural pro- duction. In Plant and Soil, vol. 174, pp. 3-28. DOI:10.1007/BF00032239.

PRATT, P.F. - BROADBENT, F.E. - MARTIN, P. 1973. Using organic wastes as nitrogen fertilizers. In California Agriculture, vol. 27, no. 6, pp. 10-13. DOI:10.3733/ca.v027n06p10.

RAUN, W.R. - JOHNSON, G.V. 1999. Improving nitrogen use efficiency for cereal production. In Agronomy Journal, vol. 91, pp. 357-363. DOI:10.2134/agronj1999.00021962009100030001x.

SRADNICK, A. - OLTMANS, M. - RAUPP, J. - JOERGENSEN, R.G. 2014. Microbial residue indices down the soil profile after long-term addition of farmyard manure and mineral fertilizers to a sandy soil. In Geoderma, vol. 226-227, pp. 79-84. DOI:10.1016/j.geoderma.2014.03.005.

WANG, H.Y. - ZHOU, J.M. - CHEN, X.Q. - LI, S.T. DU, C.W. - DONG, C.X. 2003. Interaction of NPK fertilizers during their transformation in soils: I. dynamic changes of soil pH. In Pedosphere, vol. 13, pp. 257-262.

YANG, J.Y. - DRURY, C.F. - YANG, X.M. - DeJONG, R. - HUFFMAN, E.C. - CAMPBELL, C.A. - KIRKWOOD, V. 2010. Estimating biological $\mathrm{N}_{2}$ fixation in Canadian agricultural land using legume yields. In Agriculture, Ecosystems \& Environment, vol. 137, pp. 192-201. DOI:10.1016/j.agee.2010.02.004.

ZBÍRAL, J. - HONSA, I. - MALÝ, S. 1997. Jednotné pracovní postupy [Integral working processes]. ÚKZÚZ Brno, pp. 150.

ZHANG, J. - YANG, J. - YAO, R. - YU, S. - LI, F. HOU, X. 2014. The Effects of Farmyard manure and Mulch on Soil Physical Properties in a Reclaimed Coastal Tidal Flat Salt-Affected Soil. In Journal of Integrative Agriculture, vol. 13, pp. 1782-1790. DOI: 10.1016/S2095-3119(13)60530-4.

ZHANKG, Y.G. - ZHANG. Y.Y. - CAI, J.P. - ZHU, P. GAO, H.J. - JIANG, Y. 2014. Variation in available micronutrients in black soil after 30-year fertilization treatment. In Plant Soil Environment, vol. 60, pp. 387-393.

ZHENGCHAO, Z. - ZHUOTING, G. - ZHOUPING, S. FUPING, Z. 2013. Effects of long-term repeated mineral and organic fertilizer applications on soil organic carbon and total nitrogen in a semi-arid cropland. In European Journal of Agronomy, vol. 45, pp. 20-26. DOI:10.1016/j.eja.2012.11.002.

Received: November 12, 2014 